https://doi.org/10.18485/iipe_regbezb.2021.ch9

\title{
ARKTIK KAO SEVERNA MARITIMNA KOMPONENTA KINESKE INICIJATIVE „POJAS I PUT
}

\begin{abstract}
Nenad STEKIĆ1
Apstrakt: Region Arktika postaje sve intenzivnije polje tematizacije u okviru akademskih diskusija u međunarodnim odnosima. U većini slučajeva, Arktik se već označava kao prostor od značaja za globalni mir i stabilnost, ali i kao alternativna globalna tranzitna pomorska ruta. Rastući ekonomskopolitički potencijal Narodne Republike Kine u protekloj deceniji zvanično ju je etablirao kao dominantnog aktera u svim važnijim odnosima koji se tiču ovog regiona. Cilj ovog rada jeste prikaz i analiza deklarisane bezbednosne politike NR Kine za prostor Arktika u protekloj deceniji, kao preduslovu razumevanja trenutnog stanja regionalne bezbednosti na ovom području. NR Kina opredeljuje geografski prostor Arktika kao severnopomorsku komponentu inicijative „Pojas i put“, zbog čega joj je očuvanje regionalnog mira i stabilnosti od izuzetne važnosti. Zarad ostvarivanja cilja ovog rada biće analizirana strateška i doktrinarna akta NR Kine i prikazani značajniji događaji koji oblikuju sve kompleksniju regionalnu bezbednosnu dinamiku Arktika. Autor primenjuje postulate teorije hegemonske stabilnosti u okviru koje utemeljuje Kinu kao potencijalnog "hegemona“ i usmerava analizu na njene "izazivače“ (challengers) u domenu bezbednosno-političkih interakcija. Dodatna konkretizacija istraživanja teče u pravcu identifikovanja odnosa ove azijske države sa državama koje zauzimaju geografski deo Arktika. Na bazi nivoa asertivnosti kineske bezbednosne politike prema ovom regionu, autor diskutuje o tri moguća
\end{abstract}

\footnotetext{
${ }^{1}$ Istraživač saradnik, Institut za međunarodnu politiku i privredu, Beograd.

E-mail: nenad.stekic@diplomacy.bg.ac.rs

Rad je nastao u okviru naučnoistraživačkog projekta „Srbija i izazovi u međunarodnim odnosima 2021. godine“, koji finansira Ministarstvo prosvete, nauke i tehnološkog razvoja Republike Srbije, a realizuje Institut za međunarodnu politiku i privredu tokom 2021. godine.
} 
scenarija koja će oblikovati regionalnu bezbednost ovog područja u narednoj deceniji. Nalazi ovog rada doprineće adekvatnijem razumevanju modaliteta moguće smene dominantnih aktera nad ovim područjem, kao i produbljenoj analizi potencijalnih sporova koji se mogu javiti među njima.

Ključne reči: NR Kina, pomorski Pojas i put, Arktik, regionalna bezbednost, Rusija, teorija hegemonske stabilnosti.

\section{POSTOJI LI VAKUUM MOĆI NA ARKTIKU?}

Geografski prostor Arktičkog kruga predstavlja područje unutar paralele koja se nalazi na 66. stepenu severno od ekvatora i koje obuhvata tri kontinenta i teritoriju devet zemalja. Ovaj prostor je već duže vreme predmet naučnih istraživanja zbog njegovih geografskih i bioloških specifičnosti, ali je u protekloj deceniji zauzeo značajno mesto u nauci o međunarodnim odnosima. U okviru akademske literature, Arktik je tematizovan kao entitet na koji je moguće aplicirati postulate većine teorijskih pristupa u okviru nauke o međunarodnim odnosima. Uprkos često tretiranom stanovištu prema kom na prostoru Arktika postoji vakuum moći koji otvara mesto za novog suverena (Fenge and Penikett 2009; Wegge 2011; Lukens 2013), region Arktika je već nekoliko decenija u fokusu spoljnopolitičkih ciljeva velikih sila. Studija objavljena tokom 2014. godine opisuje Arktik kao „arenu u kojoj raste gužva supersila u pogledu kontrole nad trgovačkim rutama i resursima" (Zhan and Ma 2014). Stvaranju ovakve "gužve" na Arktiku pogodovala su dva uzroka. Prvi se tiče prirodnog spleta okolnosti kojima je globalno otopljavanje dovelo do enormnog otapanja leda u delu sveta u kom se isti gotovo nikada nije topio. Proroković karakteriše proces smanjenja površina pod ledom na Arktiku kao „prvorazrednu bezbednosnu pretnju“ čije implikacije će se osetiti i na globalnom nivou $(2017,297)$. Topljenjem leda, stvaraju se velike maritimne površine slobodne za nesmetanu plovidbu, što će u bliskoj budućnosti dovesti do intenziviranja permanentnih tranzitnih ruta preko Arktika (o prirodnom fenomenu kao uzroku koji pogoduje sekuritizaciji Arktika, videti [Greaves 2019]). ${ }^{2}$

\footnotetext{
${ }^{2}$ Usled topljenja leda, broj nedelja tokom kojih je Beringov moreuz plovan kontinuirano raste $\mathrm{u}$ poslednjih deset godina. Tokom 2012. godine plovnost je bila moguća tokom 21 nedelje godišnje, dok je tokom šest nedelja na ovom području leda bilo između 10 i 40\%,
} 
Druga okolnost jeste asertivnija ekonomska uloga Kine na međunarodnom planu. Višedecenijski proces "otvaranja ka spolja“, uz snažnu izvozno orijentisanu privredu, zaokružen je uspostavljanjem inicijative Pojas i put tokom 2013. godine, koja je ubrzo prerasla i u važan politički multilateralni format. Kina većinu svojih proizvoda plasira pomorskom rutom koja je opterećena brojnim bezbednosnim pretnjama (o čemu će biti reči u nastavku teksta), pa otuda njeno nastojanje za diverzifikacijom trgovačkih i energetskih ruta ka Evropi. Sudeći po trenutno deklarisanim spoljnopolitičkim ciljevima Kine, područje Arktika predstavljaće njen glavni alternativni pomorski put ka Evropi, a kako je kao dugoročni deklarisani spoljnopolitički cilj identifikovano očuvanje mira i stabilnosti ovog područja, moguće je očekivati asertivniju arktičku politiku Kine. Intenziviranje dinamike političko-ekonomske uključenosti sve većeg broja aktera na Arktiku, u literaturi je otvorilo pitanje o etabliranju novog hegemona ovog prostora. Ima li Kina, kao rastući globalni lider, kapacitet da postane "suveren Arktika“ i koji su modaliteti legitimizacije takvog statusa na međunarodnopolitičkom planu? Odgovor na ovo pitanje je snažno povezan sa raspravama o budućim modalitetima regionalne bezbednosne dinamike Arktika. Dodatne argumente o Arktiku kao području od rastućeg geopolitičkog značaja nude i ostali autori (Røseth 2014; Daniels and Mitchell 2017; Heininen and Finger 2018), koji tvrde da će Arktik predstavljati varijablu koja će biti neizostavni deo analize odnosa između velikih sila $u$ narednoj deceniji. Oni takođe veruju u odsustvo vestfalske (tvrde nacionalne) moći u polarnom krugu, što će dovesti do težnje za ispunjavanjem tog vakuuma prisustvom nekog od dominantnih aktera. Hejninen i Finger su najoptimističniji u pogledu značaja koji će Arktik imati u bližoj budućnosti, dajući mu atribute „novog geopolitičkog konteksta" $(2018,2)$, a neka od identifikovanih svojstava ovog prostora, koji idu u prilog takvoj tvrdnji, jesu tranzitni značaj, ogromne količine bioresursa, opšta dostupnost resursima vode i energetska bezbednost (Proroković 2017, 298).

što omogućava samo delimičnu plovnost (Berkman et al. 2016, 200). Taj broj je tokom 2020. godine narastao na 23 plovne nedelje, dok se procenjuje da će u 2025. godini potpuna plovnost biti moguća tokom 25, a u 2030. godini - tokom 27 nedelja (Berkman et al. 2016, 200). Predikcije takođe ukazuju da od 2030. godine više neće postojati period godine $u$ okviru kog bi plovnost mogla biti obustavljena u celosti (Berkman et al. 2016, 200), što će konačno omogućiti stvaranje permanetnih ruta preko Severnog ledenog okeana. 
Zarad pružanja sistematičnog odgovora na ovako postavljen predmet istraživanja, autor ovog članka najpre će diskutovati o inoviranju teorijske paradigme hegemonske stabilnosti. Otvaranje novog pitanja oko kog su intenzivirana sporenja između dve vodeće supersile u svetu - SAD i Kine, zahteva širenje teorijskih premisa ka alternativnim objašnjenjima koja mogu biti primenjiva na ponašanje supersila i na "rotaciju“ pozicije hegemona. Nakon pružanja teorijskog utemeljenja "borbe“ oko Arktika, autor će predstaviti osnovne postulate na kojima je zasnovana politika kineskog strateškog prisustva u ovom delu sveta. Dva dokumenta kojima Kina legitimizuje svoje prisustvo i angažman na Arktiku su Vizija za pomorsku saradnju u okviru Pojasa i puta (2017), kao i dokument strateškog nivoa Kineska politika za Arktik (2018). Ovaj segment rada rezultiraće i uvidima o institucionalnom angažmanu Kine na Arktiku, pojedinim strateškim dilemama, kao i ostalim pitanjima koja su u vezi sa potencijalnim širenjem njene fiktivne suverenosti na Polarni krug. Poseban fokus ovog poglavlja analizira Arktik kao tranzitni prostor njene globalne inicijative Pojas i put, koja je u akademskoj literaturi označena sintagmom „polarni Pojas i put“. U poslednjem poglavlju autor diskutuje o implikacijama po „novu arktičku stvarnost" koje nastaju kao posledica odnosa Kine sa ostalim državama koje su uključene $\mathrm{u}$ formulisanje politika $\mathrm{u}$ vezi sa Arktikom, a koje su posledica dubljeg kineskog „upliva“ na Arktiku. Na bazi teorijskih premisa orijentisanih na analizu regionalne bezbednosti, autor diskutuje o tri moguća scenarija koja će oblikovati regionalnu bezbednosnu agendu Arktika u narednoj deceniji, smeštajući najintenzivniji nivo interakcija država unutar ovog regiona u teorijsku matricu regionalnog bezbednosnog kompleksa.

\section{INOVIRANJE PARADIGME HEGEMONSKE STABILNOSTI}

Jedno od najkompleksnijih pitanja u okviru nauke o međunarodnim odnosima problematizuje ostvarivanje uloge globalnog liderstva $u$ međunarodnom sistemu. Kapacitet globalne supersile da igra ulogu dominantnog aktera je polje koje je intenzivirano u okviru akademskog diskursa padom berlinskog zida i razvojem unipolarne organizacije međunarodnog sistema (Layne 2002; Ciută 2006). Rasprave o „ponašanju“ supersile tokom poslednje decenije prošlog veka, račvale su se u dva pravca: de lege lata (ka konceptualnoj tematizaciji strukture međunarodnog sistema) i de lege ferenda (ka hegemonskoj stabilnosti). Prvi pravac de lege 
lata opisuje sistem onakvim kakav jeste; sistem je ustrojen činjenicom da se na njegovom čelu nalazi hegemon. ${ }^{3} \mathrm{U}$ anarhičnom sistemu međunarodnih odnosa jedna država se izborila za premoć nad ostalim članicama sistema, koji je stabilan upravo zato što ima "dominantnog čuvara“. Drugi pravac je mahom etabliran $\mathrm{u}$ okviru teorije hegemonske stabilnosti i zastupa tezu o poželjnom (ponekada i neophodnom) ponašanju hegemona u sistemu, zarad ostvarivanja bezbednosti i ukupnog opstanka potonjeg. Ovakvo viđenje predstavlja svojevrsni desideratum (željeno stanje) u pogledu stabilnosti međunarodnog sistema. Hegemon može i mora da interveniše ukoliko je stabilnost sistema na čijem je čelu - značajno narušena ili preti njegovoj liderskoj poziciji. Problematizacija ovog pitanja naročito je intenzivnije proučavana $u$ akademskim studijama čiji su istraživački napori usmereni ka intervencionističkom delovanju SAD na prelazu između XXi XXI veka. Autori ovog pravca zastupaju (čak i opravdavaju) pojedine aktivnosti koje se tiču upotrebe sile od strane unipola, zarad opstanka i blagostanja sistema (Lakoff 1991; Bjola 2005; Fletcher and Ohlin 2008; Delahunty and Yoo 2009). ${ }^{4}$ Otuda je proistekao derivat hegemonske stabilnosti na temelju kog je razvijena i teza (teorija) o hegemonskoj stabilnosti, koja originalno predstavlja ekonomski koncept obilno apliciran u okviru nauke o međunarodnim odnosima. ${ }^{5}$ Njegov utemeljivač Čarls Kindlberger (Charles P. Kindleberger) identifikuje posedovanje moći, snažnu

\footnotetext{
${ }^{3}$ Stabilnost i trajanje sistema su dve centralne karakteristike kojima se pridodaje i treća koja se odnosi na strategiju unipola zarad očuvanja takvog statusa quo (Monteiro 2014). Ovaj rad je usmeren na prikaz teorije hegemonske stabilnosti i zbog toga se autor neće upuštati u detaljnija određenja karakteristika unipolarne organizacije sistema međunarodnih odnosa.

${ }^{4}$ Sa druge strane, Flečer i Ohlin su identifikovali šest načela kojima legitimizuju odbranu od agresije: napad mora biti nasilan (mora postojati upotreba vojne sile), mora biti ilegalan u skladu sa međunarodnopravnim normama, dok se odbrana mora zasnivati na odgovoru na napad koji je istovremen. Nije dopušteno da država koja se brani čeka zarad odmazde ili represalija $(2008,90)$. Samoodbrana mora biti neophodna, kao i proporcionalna, i mora biti planirana odnosno sprovedena voljom države koja se brani $(2008,103)$.

${ }^{5}$ Imajući u vidu da je hegemonska stabilnost analitički koncept koji je pozajmljen iz ekonomije, ne može se svrstati u korpus teorija međunarodnih odnosa. Zbog nedostatka jedinstvenog i sistematičnog metoda, kojim se mogu sprovoditi istraživanja međunarodnopolitičke pozicije ",hegemona“, kao i zbog činjenice da je u pitanju tvrdnja o sagledavanju međunarodnih odnosa sa pozicije hegemona, što isključuje sve ostale države, adekvatnije je ovaj koncept tretirati kao tezu o hegemonskoj stabilnosti. Ovo naravno ne znači negiranje teorijskog $\mathrm{u}$ hegemonskoj staiblnosti.
} 
i rastuću ekonomiju i posvećenost međunarodnom sistemu, kao tri preduslova kojima se država legitimizuje kao hegemon sistema (Kindleberger 1973, 197-198). Prema njegovom stanovištu, sistem je stabilan ukoliko je vođen od strane hegemona koji je sposoban da u svakom trenutku ima mogućnost da ga stabilizuje na efikasan način (Kindleberger 1973, 198). Pored kapaciteta koji se odnose na državnu tvrdu i meku moć, odnos hegemona i sistema mora da bude simbiotski, što implicira neophodnu posvećenost hegemona sistemu. Ukoliko je država sa najvećim korpusom moći (ekonomske, vojne ili političke) izolovana i nema želju da intenzivno "nadzire“ sistem, tada se ne može govoriti o hegemonu u smislu ove teorije. Ovako predstavljeni segmenti hegemonske stabilnosti $u$ izvornom obliku su primenjivani na analize unipolarnosti na čelu sa SAD. Međutim, okolnosti koje se odvijaju tokom protekle decenije na međunarodnom planu, ukazuju na moguću ,smenu hegemona“ u bližoj budućnosti, čiji tron će možda po prvi put biti osvojen isključivo ekonomskim i diplomatskim, a ne vojnim sredstvima, što bi potvrdilo tezu o mogućoj benevolenciji hegemonske stabilnosti (Snidal, 1985). Takva, potencijalno nova realnost sa Kinom, kao vodećom državom sistema u narednoj deceniji, zahtevaće i inoviranje paradigme na kojoj je godinama bila zasnovana teza o hegemonskoj stabilnosti, a u nastavku je pružen osvrt na segmente koji će se teorijski uobličavati u akademskom diskursu.

Prva promena paradigme hegemonske stabilnosti odnosi se na način kojim hegemon "osigurava" funkcionisanje sistema. U klasičnom viđenju ovog pitanja, hegemon na raspolaganju ima sve vrste moći, podržane kapacitetom da ih efikasno upotrebi u slučaju značajnijeg narušavanja stabilnosti od strane drugih aktera. Kinesko vojno prisustvo u svetu je $\mathrm{u}$ ogromnoj disproporciji sa njenim ekonomsko-političkim potencijalima, zbog čega će njen pristup sistemu će biti značajno drugačiji od SAD ili drugih imperijalnih prethodnika (Heath 2018). ${ }^{6}$ Osim u Džibutiju, u kom Kina ima stalno vojno prisustvo, Hit sugeriše da će moguć fokus Kine, kada je reč o

\footnotetext{
${ }^{6}$ U opsežnom izveštaju korporacije RAND (2018) koji na sistematičan način tretira kinesko vojno prisustvo u svetu, navodi se paradoks koji se tiče terminološkog analitičkog problema kineskog vojnog prisustva. Imajući u vidu da Kina nema doktrinu kojom reguliše upotrebu oružanih snaga izvan svoje teritorije, Timoti Hit (Timothy R. Heath) primećuje da je zapadnocentrični termin "globalna projekcija moći u kineskom slučaju neupotrebljiv“ te stoga predlaže alternativnu sintagmu poput "ograničene upotrebe sile izvan teritorije Kine“ $(2018,4)$.
} 
njenom vojnom prisustvu $\mathrm{u}$ drugim delovima sveta, biti usmeren ka bezbednosno osetljivim pomorskim lukama $(2018,30)$, poput onih u Indiji. ${ }^{7}$ Dodatan inovativni način kojim Kina može osigurati povećanje vojnog prisustva jeste da pomorske luke koje gradi u zemljama u razvoju imaju dualnu upotrebu, poput luke u Šri Lanki (Heath 2018, 30). Transformativni uticaj koji Kina ostavlja na države svog okruženja jeste sui generis ovladavanje globalnim sistemom, što u prvi plan postavlja benevolenciju (dobroćudnost) u njenom odnosu sa ostalim članicama sistema.

Modalitet kojim se liderska (hegemonska) pozicija menja, predstavlja drugu modifikaciju teze o hegemonskoj stabilnosti. Tumačenjem izvornih postavki teze o hegemonskoj stabilnosti prema kojima je vojna sila (i spremnost za njenu upotrebu) najvažnije preimućstvo koje poseduje hegemon, može se izvesti zaključak prema kom će Kina kao rastuća sila, gotovo izvesno projektovati svoju vojnu moć u slučaju da segmenti meke ili ekonomske moći ne daju „željene“ rezultate u ovom procesu. Međutim, imajući u vidu dosadašnju vojnu inertnost Kine teško je očekivati njenu direktnu vojnu konfrontaciju sa drugim državama u sistemu, a naročito sa velikim silama. Najskoriji primer promene organizacije međunarodnog sistema iz bipolarnog u unipolarni, koji se dogodio početkom poslednje decenije XX veka, pokazuje da direktna vojna konfrontacija između aktuelnog hegemona i pretendenta ne njegovo mesto nije preduslov etabliranja hegemona, ali da je vojno "dokazivanje“ posredstvom vojnih intervencija u različitim delovima sveta, koje je karakterisano sukobom ograničenih razmera, neophodno zarad „održanja“ sistema.

Treća, i ujedno poslednja, modifikacija teze o hegemonskoj stabilnosti potencijalno obuhvata dimenziju regionalnog hegemonstva. Uspostavljanje regionalne hegemonije nad određenim područjem ne mora značiti pretenzije ka globalnom hegemonstvu. Otuda ovakva postavka nema veze sa klasičnim geopolitičkim Mekinderovim silogizmom što bi se prvo moglo pomisliti, a koji reguliše uspostavljanje globalne geopolitičke hegemonije postepeno, posredstvom ovladavanja manjim geografskim celinama (Mackinder 1904). Na početku ovog rada izneta je nekolicina argumenata o Arktiku kao regionu sa rastućim međunarodnopolitičkim značajem.

\footnotetext{
${ }^{7}$ Prema podacima iz izveštaja RAND-a iz 2018. godine, kinesko vojno prisustvo u svetu je veoma skromno. Mesečno angažovanje Narodnooslobodilačke armije Kine, tokom 2017. godine u svetu, nije prelazilo 4.000 pripadnika, a svega šest ratnih brodova isplovilo je izvan teritorijalnih voda Kine (Heath 2018, 32).
} 
Umesto fokusa na tzv. mainstream regione, koji u okvirima međunarodnih odnosa zauzimaju „značajno“ $i$,strateško“ mesto, Kina svoje prisustvo u određenim delovima sveta temelji na pragmatsko-ekonomskoj osnovi. Takva promena motiva za uključivanje $u$ regionalna pitanja $u$ odnosu na modalitete koji su se javljali u prethodnom periodu, predstavlja novu vrstu asertivnosti u međunarodnim odnosima. Sve pobrojane premise, na bazi kojih je izvršena modifikacija originalne zamisli hegemonske stabilnosti, upućuju na sužavanje istraživačkog opsega analiziranih fenomena. Hegemonsku stabilnost je moguće aplicirati na objašnjenje unipolarnog sistema i borbu unipola sa pretendentima na njegovu poziciju. Međutim, u protekloj deceniji, na međunarodnopolitičkom planu se NR Kina etablira kao akter sa specifičnim rastom koji je oblikovan intenzivnijim prisustvom u regionima koji naizgled nisu od prvorazrednog međunarodnog značaja, poput Arktika.

\section{POLARNI „POJAS I PUT": STRATEGIJA KINE ZA ARKTIK}

Stvaranje inicijative „Pojas i put", inicijalno je predstavljalo logističku podršku izvozno orijentisanoj industriji Kine na globalnom planu. Tadašnji predsednik Kine, Si Đinping opisao je kao „inovativni pristup u ekonomskoj izgradnji novih kineskih snova" (Tillman et al. 2018). Ovako postavljen projekat je prema akademskim tumačenjima trebalo da omogući dvostruku globalnu suprematiju Kine nad evroazijskom kopnenom masom, kao i nad pomorskom rutom kroz Indijski okean (Fasslabend 2015, 297). Međutim, ogromna većina kineskog izvoza, nasuprot tradicionalnim kopnenim rutama duž prostora Evroazije, danas se odvija pomorskim alternativnim pravcima, zbog čega je pomorski saobraćaj šire tematizovan u akademskoj literaturi. ${ }^{8}$ Geografski logičan (i doskora jedini) maritimni

\footnotetext{
${ }^{8}$ Pomorski transport robe preuzeo je primat u odnosu na kopneni već 2015 . godine. Prema proračunima Vanga Liehuija (Wang Liehui) i saradnika, broj destinacija iz deset najvećih kineskih luka ka istočnoj Africi, južnoj Aziji, Evropi i zapadnoj Aziji u periodu između 1995. i 2015. godine je desetostruko uvećan (Wang et al. 2018). Dodatno, oni primećuju da se od 2010. godine struktura pomorskih ruta iz jednolinearne hijerarhijske (u kom su dominantnu ulogu igrale najveće kineske luke), sada transformisao u mrežne sa više sedišta i izvoznih centara (Wang et al. 2018, 9).
} 
put ka zapadnim tržištima kreće se od kineskih luka preko Malajskog moreuza, dalje obalama Indije i nastavlja ka Persijskom zalivu, ili pak preko Sueca ulazi na područje Sredozemnog mora, odakle ide ka lukama u Evropi. Duž ove rute postoji mnogo bezbednosnih rizika po trgovačke brodove, a najizraženije tačke nesigurnosti su Malajski moreuz, zatim tzv. "indijska ruta", kao i prolazak međunarodnim vodama (Starr 2013). Referišući na pitanje sigurnosti trgovačke plovidbe, tadašnji kineski predsednik Hu Đintao (Hu Jintao) je 2003. godine skovao sintagmu „malajska dilema“, kojom je označio bezbednosnu zebnju Kine u pogledu ovog geografskog područja (naročito Malajskog moreuza), koja se tiče tranzitnih trgovačkih brodova. Obraćajući se prisutnima na ekonomskoj konferenciji Komunističke partije Kine, on je ukazao na mogućnost napada na brodove od strane nedržavnih aktera, poput terorističkih grupa i pirata, i dodao da ostale države mogu namerno opstruirati kontinuiran tranzit na ovom području (Storey 2006). Dilema Malajskog moreuza je intenziviranjem kineskog izvoza reaktuelizovana u protekloj deceniji, a pojedina stanovišta uvažavaju dve brige u vezi s njom: očuvanje strateških interesa Kine u Moreuzu, kao i variranje bilateralnog odnosa sa državama zapadne hemisfere koje bi mogle narušiti sigurnost plovidbe i time ograničile kineski izvoz (Lanteigne 2008, 153). ${ }^{9}$ Iako je inicijalno ispoljena kao briga za sigurnost trgovačke plovidbe, dilema Malajskog moreuza zapravo supstantivno zadire u energetsku bezbednost Kine, imajući u vidu da se celokupan prevoz energenata iz država Persijskog zaliva obavlja ovom rutom (Ji 2007; Leung 2011; Zhang 2011). Međutim, Malajski moreuz nije jedini bezbednosni problem za nesmetanu plovidbu kineskih trgovačkih brodova. Tenzije i nestabilnost Bliskog istoka, a naročito politička previranja koja su bila izražena u Egiptu u protekloj deceniji, narušila su bezbednost tranzitnih brodova u Sueckom kanalu (Starr 2013; McNicholas 2016).

Zbog izraženih problema sa tradicionalnom maritimnom rutom i mogućnošću opstrukcije od strane drugih država, ali i geografskih i prirodnih faktora kojima je olakšana plovidba na polarnom krugu, Kina se $\mathrm{u}$ poslednjih nekoliko godina fokusirala na formulisanje adekvatne strategije kojom bi omogućila plovidbu alternativnom maritimnom rutom

\footnotetext{
${ }^{9}$ Podrobnije diskusije u pogledu strateških opcija za zvanični Peking povodom dileme malajskog moreuza, kao i o ostalim faktorima koji oblikuju kinesku politiku prema ovom regionu, videti u: Lanteigne 2008.
} 
koja se prostire duž Arktika. Procene su da bi korišćenje severne pomorske rute skratilo prevoz tereta za 10 do 20 dana u odnosu na korišćenje rute koja uključuje korišćenje Sueckog kanala (Maçães 2018, 55; Lađevac 2020). Rutom kroz Severni ledeni okean prvi put su dva trgovačka broda prošla tokom 2009. godine, dok je do 2012. godine taj broj narastao na 46 brodova (DW 2013). Tranzit prvih brodova 2009. godine okarakterisan je od strane Stokholmskog instituta za proučavanje mira kao „priprema Kine za otopljen Arktik“ (Jakobson 2010). Sistematizovani podaci za broj tranzitnih prelaza u Beringovom moreuzu su dostupni od 2008. godine, kada je zabeleženo 220 brodova koji su prošli kroz moreuz (Fletcher 2016, 16). Od tada, brojke kontinuirano rastu na godišnjem nivou, a 2015. godine je moreuzom prošlo 540 plovila (Fletcher 2016, 16).

Olakšavanje prirodnih uslova za plovidbu i njeno intenziviranje proizveli su potrebu za sveobuhvatnijom kodifikacijom kineske politike za Arktik, koja je izvršena kroz dva značajna akta - Vizije za pomorsku saradnju u okviru inicijative "Pojas i put" (usvojena 2017. godine), kao i strateškog dokumenta „Kineska politika za Arktik“. Potonji dokument, zbog svoje važnosti, tretira se kao najznačajniji akt koji služi kao osnova za formulaciju trenutne kineske politike na Arktiku. Ovim strateškim aktima prethodila je institucionalizacija učešća Kine u regionalnim pitanjima, imajući u vidu da je 2013. godine Kina dobila status posmatrača u okviru Arktičkog saveta (Arctic Council 2020), jednog od najznačajnijih multilateralnih formata posvećen formulaciji i primeni različitih sektorskih politika na prostoru Arktika.

Vizijom za pomorsku saradnju u okviru inicijative "Pojas i put", istaknuto je stvaranje tzv. "plavih ekonomskih prolaza“, maritimnih ruta kojima bi se ekonomski dodatno povezale Afrika, Evropa i Okeanija sa Kinom (BRF IC 2017). Jedan od tri plava ekonomska prolaza, koja su identifikovana ovim dokumentom, trebalo bi da poveže Evropu sa Kinom i vodama Severnog ledenog okeana. Kao jedan od principa na kojima počiva ovaj dokument navodi se prosperitet izgrađen na bazi korišćenja pomorskih ruta. Vizija navodi povećanje učešća Kine $u$ pitanjima od značaja za Arktik, poput naučnih proučavanja Arktika i Severnog ledenog okeana kao područja koja imaju značaj za razvoj čovečanstva, navodeći da će Kina aktivno biti involvirana u sve događaje i rad međunarodnih organizacija koje se tiču Arktika (BRF IC 2017). Dodatno, principi na kojima se zasniva ovaj dokument odnose se na izgradnju konsenzusa u pogledu korišćenja prostora Arktika, otvorenosti i saradnje na tom polju (BRF IC 
2017). Vizijom su navedeni i praktičnopolitički principi na kojima se zasniva kineska Vizija za pomorsku saradnju u okviru inicijative Pojas i put, kojima je zasnovano učešće $u$ tržišnim potrebama i uključivanje šireg spektra učesnika u ovom procesu, poput nacionalnih vlada, industrije, civilnog društva i privatnih korporacija (BRF IC 2017). Ovaj akt na posredan način tretira uključivanje Kine u arktička pitanja i predstavlja nešto opštiju osnovu kojom se identifikuju njeni pomorski interesi u okviru inicijative Pojas i put.

Konkretizacija arktičke politike Kine učinjena je godinu dana kasnije kada je usvojen tzv. beli papir "Kineska politika za Arktik“. Preambulatorni deo ovog dokumenta naglašava rastuću vrednost ovog regiona na strateškom, ekonomskom, maritimno-plovnom i naučnom potencijalu (SC PRC 2018), pridajući mu atribute regiona čiji značaj prevazilazi geografsko područje država polarnog kruga. Time je ovim dokumentom Arktik označen kao svojevrsni res comunis omnium, koji, prema stanovištu zvaničnog Pekinga, ne pripada samo državama koje su u njegovom neposrednom geografskom krugu, već celokupnom čovečanstvu. Dokument kojim je Kina ispoljila svoje osnovne principe politike za Arktik sastoji se iz pet celina u kojima se detaljnije razmatraju pitanja kineske pozicije u učešću u pitanjima koja se tiču Arktika, identifikujući kao najznačajnije: produbljivanje istraživanja i razumevanja Arktika, zaštitu životne sredine Arktika, korišćenje arktičkih resursa, aktivno učešće u upravljanju Arktikom, kao i promociju mira i stabilnosti na Arktiku (2018). Dokument konstatuje da je otapanje ledenih površina, uzrokovano klimatskim promenama, otvorilo put ka strateškom razvoju Arktika kao regiona od globalnog značaja za prekomorske tranzitne rute, ali i međunarodnu trgovinu, kao i snabdevanje energentima (SC PRC 2018). Sveukupna nastojanja Kine da se etablira kao relevantan akter na području Arktika, ali i da uspostavi svoje maritimne tranzitne rute, što je izraženo u Strategiji iz 2018. godine sintagmom „Polarni Pojas i put",postala su opšteprihvaćena u akademskoj literaturi (Tillman et al. 2018; Lim 2018; Blaxekjær et al. 2018; Gladkiy 2020).

Komentarišući beli papir o Arktiku, neposredno nakon njegovog usvajanja 2018. godine, zamenik ministra spoljnih poslova Kine, Suanjou Kong (Xuanyou Kong), sumirao je (tada) novousvojen dokument u četiri tačke. Prva se tiče razloga za usvajanje ovog akta; Kina smatra da postoji neophodnost definisanja njenog uključivanja $u$ arktička pitanja, te je stoga formulacija u obliku akta koji odražava zvaničnu politiku - potrebna (MFA PRC 2018). Druga tačka se odnosi na empatiju Kine prema ostalim 
državama $\mathrm{u}$ međunarodnom sistemu. Kong je istakao da status i pozicionisanje Kine u međunarodnim odnosima predstavlja ,zajednički interes svih država međunarodne zajednice“. Treća tačka se tiče poštovanja principa za učešće na Arktiku. Kina, prema rečima Konga, propagira principe poštovanja, saradnje i tzv. „win-win ishoda eksploatacije Arktika i tranzita“" (MFA PRC 2018). Poslednja, četvrta premisa koju je elaborirao Kong tiče se utvrđivanja strateških pozicija Kine u Arktiku, odnosno preciziranje ciljeva kineske spoljne politike i odnosa prema ovom regionu (MFA PRC 2018).

King Lim (King Lim) (2018) identifikovao je, na bazi govora zamenika kineskog ministra spoljnih poslova, dva cilja Kine: da ne prekorači svoju geografsku i političku poziciju, i s druge strane da ne ostane inertna po pitanju Arktika. U prvom slučaju Kina će, prema Limovim tvrdnjama, priznati da ne pripada krugu arktičkih država, te stoga "neće intervenisati u pitanjima koja se tiču arktičkih država niti unutar regiona“. Nasuprot tome, stoji princip asertivnosti, koji naglašava da Kina „ne može biti odsutna", te da će učestvovati u međuregionalnim pitanjima koja se posredno tiču regulisanja odnosa na Arktiku (Lim 2018, 3). Lim pruža argument prema kom je malo izvesno da će, uprkos svom prisustvu na Arktiku, Kina ipak zadržati neutralni pristup po pitanju polaganja prava na suverenost nad pojedinim geografskim područjima koja su sada predmet sporenja $(2018,3)$.

\section{ASERTIVNOST BENEVOLENTNOG HEGEMONA I REGIONALNA BEZBEDNOSNA DINAMIKA ARKTIKA}

Jedna od ključnih slabosti teorije hegemonske stabilnosti bazirana je na preliminarnoj pretpostavci prema kojoj je hegemon „subjekat koji obezbeđuje benefite celoj zajednici“ (Hinnebusch 2007). Hajnbaš (Hinnebusch) (2007) navodi da u sistemu međunarodnih odnosa hegemon favorizuje njegov status quo, te da svaka potencijalna promena sistema predstavlja izazov njegovoj liderskoj poziciji. Ovakva kritika bazirana je na Snidalovom (Duncan Snidal) viđenju hegemonske stabilnosti kao neodrživog koncepta imajući $\mathrm{u}$ vidu da teorija hegemonske stabilnosti vidi međunarodni sistem kao ,javno dobro“ hegemona, umesto kompleksnog sistema sa velikim brojem jedinica i interakcija među njima (Snidal 1985). Primena postulata teorije hegemonske stabilnosti na rast Kine relativno je 
skromna u akademskoj publicistici i oni uglavnom tretiraju opštu politiku ove države kao preduslov i instrument njenog hegemonstva u budućnosti (Kim and Gates 2015; Goh 2019). Jakobson i Peng (2012) smeštaju analizu politike za Arktik u okviru definisanih spoljnopolitičkih ciljeva Kine, što se odnosi na ostvarivanje političke stabilnosti, očuvanje suverenosti i teritorijalne celovitosti, kao i omogućavanje stabilnog ekonomskog i društvenog razvoja Kine. Oni veruju da je u periodu pre 2010. godine, angažman Kine na Arktiku bio motivisan njenim nastojanjima za ekonomskim razvojem kao spoljnopolitičkim ciljem, a ne težnjom za obezbeđivanjem globalnog liderstva (Jakobson and Peng 2012). Međutim, $\mathrm{u}$ svetlu novih okolnosti u međunarodnoj zajednici, ovi autori zastupaju tezu prema kojoj je, osim značajno skraćenih pomorskih tranzitnih ruta, uključivanje Kine $\mathrm{u}$ arktička pitanja motivisano njenom namerom za samopromovisanjem kao respektabilnog partnera na globalnom planu (Jakobson and Peng 2012, 20). Stvaranje „harmonične (evro)Azije“ uključuje identifikaciju političkog poretka oblikovanog kineskim političkim principima, priznavanje pitanja koja su relevantna za bezbednost Kine, ekonomska integracija predvođena Kinom i jači azijski kulturni identitet (Flint and Zhu 2019, 4). Zbog toga je transformativni potencijal Pojasa i puta označen kao atribut kojim se vrše nastojanja Kine, da posredstvom ove inicijative, izvrši preoblikovanje geografskog područja koje prevazilazi prostor Azije. Konačno, korišćenje severne rute će povećati značaj Beringovog prolaza koji geografski dele dva ključna izazivača Kine na području Arktika - Ruska Federacija i SAD. Imajući u vidu geografske odlike ovog moreuza, postoji nekoliko specifičnosti međunarodnopravnog upravljanja ovim prostorom. Berkman i saradnici (2016) navode da u ovom prolazu ne postoje međunarodne vode, imajući u vidu da, saglasno međunarodnom pravu, obe granične države imaju svoje teritorijalne vode koje se međusobno graniče. Na bilateralnom nivou je 1990. godine dogovoreno da zbog postojanja tri Diomedova ostrva, Beringov prolaz zapravo predstavlja četiri manja moreuza podeljenih između SAD i Ruske Federacije (Berkman et al. 2016, 190). Oni dalje razrađuju primenu međunarodnopravnih normi na tranzitne brodove trećih strana i opisuju ovaj geografski prostor sintagmom "usko pomorsko grlo sveta“ (Berkman et al. 2016, 191). ${ }^{10}$ Tendencija Kine da se etablira kao „bliskoarktička“ država

${ }^{10}$ Za iscrpnu međunarodnopravnu analizu Beringovog moreuza, videti više u: Owens 2011; Hartsig et al. 2012; Berkman et el. 2016. 
u saglasju je sa klasičnim teorijskim postulatima hegemonske stabilnosti i odgovaraju Kindlbergerovom preduslovu o "posvećenosti hegemona“ sistemu (Kindleberger 1973). Međutim, ovakvo nastojanje nije primilo podršku njenih glavnih „,izazivača“ u međunarodnoj areni. U januaru 2021. godine, državni sekretar SAD Majk Pompeo (Mike Pompeo) osporio je tvrdnju o Kini kao „bliskoarktičkoj” državi, tvrdeći da se njene granice nalaze na čak 1.450 kilometara udaljenosti od Polarnog kruga (Langley 2021). Pompeo je ovakvu ideju označio „komunističkom fikcijom“ (Langley 2021). Uspostavljanje novog suverena nad Arktikom može nastati kao posledica tendencije Kine da kreira sigurnu rutu za svoje trgovačke brodove kako bi izbegla ponavljanje dileme Malajskog moreuza. Hamza navodi da će zbog diverzifikacije snabdevanja energentima (kao ključnog podsticaja Kini za potragu za alternativnim rutama), dilema Malajskog moreuza biti oslabljena i marginalizovana u narednoj deceniji (Hamzah 2017).

Takva snažna želja Kine da svim sredstvima očuva bezbednost severne rute, $\mathrm{u}$ perspektivi bi mogla atributirati Arktik kao novi regionalni bezbednosni kompleks. Osim kraćeg vremena koje je potrebno trgovačkim brodovima da dođu do severne Evrope, Rozet identifikuje nedostatak infrastrukture, loše vremenske uslove, kao i znatno nizak nivo mogućnosti za pružanjem usluga potrage i spasavanja u vanrednim okolnostima (Røseth 2014). Nesumnjivo je da se asertivnost Kine ispoljena ka prostoru Arktika uklapa u sve tri predložene modifikacije teorije hegemonske stabilnosti. U pitanju je progresivna dominacija koja favorizuje regionalnu nad globalnom dominacijom; takva hegemonija nije ostvarena vojnom silom, niti ima izgleda da bi ovakav modalitet mogao da se ostvari u skorijoj budućnosti; na kraju, nema izgleda da će hegemonija nad Arktikom uzrokovati sukob većih razmera među velikim silama, izazivačima Kine na ovom prostoru - Ruskom Federacijom i/ili SAD. U zavisnosti od modaliteta ispoljavanja namere za hegemonijom i nivoom asertivnosti Kine na ovom području, moguća su tri izgleda regionalne bezbednosne dinamike Arktika tokom naredne decenije.

Prvi izgled arktičke bezbednosne dinamike uključuje status quo međudržavni odnosi i konstelacija snaga na Arktiku ostaju isti uz stagnaciju malog broja brodova koji prolaze arktičkom rutom i održavanje inertnosti plovidbe. Ovaj modalitet je izvestan u dva slučaja: zbog sprečavanja prisustva ledolomaca na ovom prostoru i usporavanja prirodnog otopljavanja leda, i zbog dodatnog međunarodnopravnog regulisanja plovidbe Severnim ledenim okeanom kojim bi se opstruirali tranziti 
brodova na ovom području. Pojedine zajedničke aktivnosti, poput izgradnje gasnog postrojenja na ruskom poluostrvu Jamal od strane Rusije i Kine, idu u prilog osiguranju zajedničke saradnje i sprečavanja sporova koji mogu nastati u vezi sa Arktikom. Značaj pojačava i činjenica da ovaj energetski projekat predstavlja prvi završen projekat na Arktiku od uspostavljanja inicijative Pojas i put (Lađevac 2020).

Međutim, ukoliko bi u analizu bila uključena i potencijalna namera Ruske Federacije za revizionističkom agendom Arktika, tada bi se moglo reći da će multilateralni odnosi na Arktiku ići u pravcu drugog modaliteta saradnje. On bi podrazumevao svojevrsni kooperativni model u okviru kog sve države ravnopravno tretiraju Arktik kao res comunis omnium i koji je karakterisan odsustvom značajnijih sporova na bilateralnom nivou. Ovaj scenario, međutim, ne isključuje sporadične incidente manjeg obima poput opstruiranja plovidbe kineskih brodova koji će zavisiti od nivoa involviranosti Kine. Son Lim sumira dosadašnju akademsku debatu o arktičkim ambicijama Kine na idealiste, koji je vide kao kooperativnog partnera na ovom prostoru (Alexeeva and Lasserre 2012; Liu 2017 navedeno prema: Lim 2018) i na pragmatski orijentisane autore (Wright 2011 navedeno prema: Lim 2018), koji prema njegovom stanovištu, veruju da postoji znatna diskrepanca između deklarisanih spoljnopolitičkih ciljeva i prakse Kine na Arktiku. Imajući u vidu aktuelnu međunarodnopolitičku praksu, koja se već ispoljava na ovom prostoru, može se reći da je ovaj scenario u pojedinim segmentima već zastupljen na Arktiku.

Treći izgled koji bi mogao oblikovati regionalnu bezbednosnu dinamiku Arktika, pretpostavlja stvaranje novog koherentnog regionalnog bezbednosnog kompleksa ovog regiona. U septembru 2015. godine, pet brodova kineske ratne mornarice izvršilo je tranzit preko teritorijalnih voda SAD na području Aleutskog arhipelaga u nameri da prođu Beringov prolaz i uđu u područje polarnog kruga, što je od strane Pentagona, iako u saglasju sa međunarodnim pravom, predstavljalo vojnu provokaciju (Page and Lubold 2015). Imajući u vidu da Arktik definitivno ne predstavlja tipičan region, uslovi koji „pogoduju“ regionalnoj bezbednosti ovog prostora, daleko su od mainstream-a (Lanteigne 2016,3). Lanten argumentuje svoj stav navodeći da geografska i demografska stvarnost ovog prostora negiraju balansiranje posredstvom tvrde, vojne moći $(2016,3)$. Nurlan Alijev (Nurlan Aliyev) (2019) navodi da Rusija od 2000. godine pokušava da povrati svoje vojno prisustvo u regionu Arktika kako bi obezbedila kontrolu nad 
prirodnim resursima. On navodi da Rusija ima najveći broj ledolomaca na svetu -40, koji su pozicionirani u vodama Severnog ledenog okeana.

Literatura o Arktiku kao regionalnom bezbednosnom kompleksu je obilna (Røseth 2014; Chater and Greaves 2014; Greaves 2019). Prema najdominantnijem stavu jedne od mogućih analitičkih teorija koja tretira regionalnu bezbednost, Arktik bi zbog svojih geografskih osobenosti mogao poprimiti odlike tzv. nestrukturisanog bezbednosnog regiona (Buzan and Wæver 2003, 62). Navodi Berija Buzana (Barry Buzan) i Ulea Vejvera (Ole Wæver) upućuju da geografija kao varijabla predstavlja jednu od dva moguća uzroka za stvaranje nestrukturisanog bezbednosnog regiona, pored niskog kapaciteta država da svoju vojnu moć projektuju izvan svoje teritorije $(2003,62)$. Arktik se uklapa u Buzanove i Vejverove premise $\mathrm{o}$ "geografskoj izolaciji ili područjima odvojenim velikim okeanskim prostranstvima“ $(2003,62)$, što u praksi onemogućava stvaranje regionalnog bezbednosnog kompleksa. Sa druge strane, pojedini autori poput Vilfreda Grivsa (Wilfrid Greaves), vide Arktik kao insulator koji razdvaja severnoamerički, evropski i postsovjetski kompleks $(2019,3) \cdot{ }^{11} \mathrm{On}$ navodi da je arktički bezbednosni kompleks nastao kao posledica desekuritizacije odnosa između supersila početkom poslednje decenije XX veka, i kao posledica prirodnih fenomena koji se tiču globalnog otopljavanja (Greaves 2019, 3). Grivs produbljuje svoju analizu praveći distinkciju arktičkog bezbednosnog kompleksa na severnoamerički, evropski i evroazijski. Ovaj autor pojašnjava da potkompleksi u slučaju Arktika ipak nisu toliko nezavisni, već da odnosi i prakse u okviru potkompleksa kojima se oblikuje bezbednosna dinamika tih regiona zavise isključivo od aktera na subregionalnom nivou, a ne na nivou regionalnog "superkompleksa“ (Greaves 2019, 5). Konkretizujući svoje viđenje arktičkog bezbednosnog kompleksa, Grivs utvrđuje geopolitičku matricu mogućeg razvoja Arktika koja se ogleda u dva moguća ishoda - atlantifikaciji ili pacifikaciji $(2019$, 910). U prvom slučaju, bezbednost Arktika će direktno zavisiti od odnosa snaga među partnerima sa obe strane Atlantika - Evrope i SAD, a sam

\footnotetext{
${ }^{11}$ Prema navodima tvoraca teorije regionalnog bezbednosnog kompleksa, insulator je lokacija koju zauzima jedna ili više jedinica, na kojoj se prepliću šire regionalne bezbednosne dinamike (Buzan and Wæver 2003, 41). Buzan i Vejver takođe vrše distinkciju između tradicionalno shvaćene "tampon zone“ i njihovog koncepta insulatora, navodeći da se potonji odnosi na nešto nijansiraniji vid tampon zone koji karakteriše veća promenljivost $(2003,41)$.
} 
arktički bezbednosni kompleks će se podeliti na dva manja severnoamerički i severnoevropski (Greaves 2019, 6-7). Pacifikacija kao drugi mogući ishod, odnosi se na stvaranje jednog subregiona na prostoru Arktičkog okeana, koji je dominiran od strane Evroazije, prevashodno Ruske Federacije i čija će bezbednost zavisiti od konstelacije odnosa na prostoru Evroazije (Greaves 2018, 9). U modelu pacifikacije, bezbednost Arktika će biti određena kroz odnos Rusije i Kine kao dve centralne sile na prostoru Evroazije (Greaves 2018, 10). Na bazi aktivnosti Rusije koje su usmerene na remilitarizaciju Arktika, kao i ispoljene zabrinutosti SAD, Kanade i skandinavskih zemalja zbog pozicioniranja Kine na ovom prostoru, opravdano je pretpostaviti da će treći scenario koji će etablirati Arktik kao regionalni bezbednosni kompleks - biti najizgledniji.

\section{ZAKLJUČNA RAZMATRANJA}

Ovaj rad je prikazao strateška opredeljenja Kine na području Arktika, koja su intenzivirana prirodnim procesima (topljenje leda i povećanje plovnosti ove rute), ali i njenom težnjom za diverzifikacijom izvoznih pomorskih ruta na globalnom planu. Zbog svih identifikovanih pitanja koja će se javljati u vezi sa Arktikom, ne čude brojni pozivi za daljim empirijskim proučavanjima odnosa među akterima $u$ „,arktičkoj utakmici“ (Øverland 2010; Wegge 2011). Prikazom najznačajnijih spoljnopolitičkih prioriteta Kine na prostoru Artika, ustanovljeno je da se Kina promoviše kao dominantna sila kojoj je geografski prostor Arktika neophodan zarad očuvanja funkcionisanja ekonomskog globalnog sistema. Ovo je potvrđeno njenim samodeklarisanjem kao „bliskoarktičke“ države u strategiji iz 2018. godine i potvrdom o njenoj posvećenosti ovom regionu, ne samo u smislu korišćenja tranzitnih prava, već i u naučnim ispitivanjima, održanju ekološke bezbednosti kao i doprinosu u borbi protiv globalnog otopljavanja. Dodatno, imajući u vidu da je Ruska Federacija najdominantnija priobalna država, malo je verovatno da bi Kina mogla da obezbedi koherentno i međunarodno priznato vojno prisustvo na ovom prostoru. Maritimne bezbednosne pretnje koje se ispoljavaju u vidu piraterije, kao i ostali konvencionalni vidovi ugrožavanja sigurnosti plovidbe, gotovo izvesno neće biti prisutni na prostoru Severnog ledenog okeana, što ne znači da će ova ruta biti potpuno bezbedna. Najpre, usled logističkih i prirodnih prepreka, poput ogromnih ledenih santi, može da se naruši kontinuitet plovidbe. Dodatno, moguće je 
da će na međunarodnopravnom nivou biti inicirano mnoštvo instrumenata kojima će se ograničiti ili bar smanjiti intenzitet plovidbe za kineske brodove. Gotovo je izvesno da će (zapadne) države usled ogromnog rasta Kine, nastojati da osujete potpunu dominaciju nad Arktikom u bližoj budućnosti.

Svi prethodno navedeni faktori će, konačno, uticati na oblikovanje regionalne bezbednosti Arktika $u$ formatu regionalnog bezbednosnog kompleksa čija dinamika će se dalje usložnjavati. U načelu se može prihvatiti Grivsova distinkcija Arktika na dva, odnosno tri potkompleksa, kao i geopolitička matrica ishodišnih procesa na atlantifikaciju i paficikaciju, prema kojima će se razvijati regionalna bezbednosna dinamika ovog dela sveta. Imajući u vidu da će globalna bezbednost u narednoj deceniji biti izraženo usložnjena, može se očekivati da će se karakteristike odnosa moći "preliti“ i na prostor Arktika u zavisnosti od odnosa na globalnom planu. Stoga je gotovo izvesno da se Arktik neće pretvoriti u prostor sa autentičnom i izolovanom bezbednosnom dinamikom, već će predstavljati svojevrsni odraz onoga što se dešava na globalnom planu. Promovisanje Kine kao suverena Arktika biće ispoljeno u meri u kojoj joj je značajan tranzit, a geopolitička dominacija nad regionom zarad ostvarenja drugih spoljnopolitičkih ciljeva u međunarodnim odnosima, što će postepeno kreirati novu „arktičku stvarnost".

\section{BIBLIOGRAFIJA}

Aliyev, Nurlan. 2019. "Russia's Military Capabilities in the Arctic", ICDS, June 25. https:/ / icds.ee/en/russias-military-capabilities-in-the-arctic

Arctic Council. 2020. "People's Republic of China". The Arctic Council. Accessed 4 January 2021. https://arctic-council.org/en/about/ observers/non-arctic-states/peoples-republic-of-china

Berkman, Artur, Alexander Vylegzhanin and Oran Young. 2016. "Governing the Bering Strait region: current status, emerging issues and future options". Ocean Development \& International Law 47 (2): 186-217.

Bjola, Corneliu. 2005. "Legitimating the use of force in international politics: A communicative action perspective". European Journal of International Relations 11 (2): 266-303.

Blaxekjær, Lau, Marc Lanteigne and Mingming Shi. 2018. “The Polar Silk Road \& the West Nordic Region". Arctic yearbook 8 (4): 437-455. 
[BRF IC] Belt and Road Forum for International Cooperation. 2017. “Full Text: Vision and actions on jointly building Belt and Road", Accessed 5 January 2021. beltandroadforum.org/english/n100/2017/0410/c2245.html

Buzan, Barry and Ole Waever. 2003. Regions and powers: the structure of international security. Cambridge: Cambridge University Press.

Chater, Andrew and Wilfrid Greaves. 2014. "Arctic Security Governance". In: Handbook on Governance and Security, edited by James Sperling, 133147. London: Elgar Publishing.

Ciută, Felix. 2006. "What Are We Debating? IR Theory between Empire and the 'Responsible' Hegemon". International Politics 43 (2): 173-196.

Daniels, Kelly and Sara McLaughlin Mitchell. 2017. "Bones of democratic contention: Maritime disputes". International Area Studies Review 20 (4): 293-310.

Delahunty, Robert and John Yoo. 2009. “The Bush Doctrine: Can preventive war be justified". Harvard Journal of Law and Public Policy 32 (1): 843-859.

[DW] Deutsche Welle. 2013. „Kinezi dolaze kroz Ledeno more“. Septembar 9. https://www.dw.com/sr/kinezi-dolaze-kroz-ledeno-more/a-170 75222

Fasslabend, Werner. 2015. "The Silk Road: a political marketing concept for world dominance". European View 14 (2): 293-302.

Fenge, Terry and Tony Penikett. 2009. The Arctic vacuum in canada's foreign policy. Ottawa: Policy Options.

Fletcher, George and Jens Ohlin. 2008. Defending humanity: when force is justified and why. Oxford: Oxford University Press.

Fletcher, Sara. 2016. Bering Sea Vessel Traffic Risk Analysis. Alaska: Nuka Research and Planning Group.

Flint, Colin and Cuiping Zhu. 2019. "The geopolitics of connectivity, cooperation, and hegemonic competition: The Belt and Road Initiative". Geoforum 99 (1): 95-101.

Gladkiy, Yu. 2020. "Polar Silk road": project implementation and geo-economic interests of Russia and China. Bristol: IOP Publishing.

Goh, Evelyn. 2019. “Contesting Hegemonic Order: China in East Asia". Security Studies 28 (3): 614-644. 
Greaves, Wilfred. 2018. "Colonialism, statehood, and Sámi in Norden and the Norwegian high north". Human and Societal Security in the Circumpolar Arctic 12(1): 100-121.

Greaves, Wilfrid. 2019. “Arctic break up: Climate change, geopolitics, and the fragmenting Arctic security region". Redefining Arctic Security: Arctic Yearbook 4 (1): 156-172.

Hamzah, Bertnard. 2017. "Alleviating China's Malacca Dilemma", ISDP, March 13. https:/ / isdp.eu/alleviating-chinas-malacca-dilemma

Hartsig, Andrew, Ivy Frederickson, Carmen Yeung and Stan Senner. 2012. "Arctic bottleneck: protecting the Bering Strait Region from increased vessel traffic". Ocean \& Coastal 18 (3): 35-49.

Heath, Timothy. 2018. China's pursuit of overseas security. Santa Monica: RAND Corporation.

Heininen, Lassi and Matthias Finger. 2018. “The 'Global Arctic' as a New Geopolitical Context and Method". Journal of Borderlands Studies 33 (2): 199-202.

Hinnebusch, Raymond. 2007. "The US invasion of Iraq: Explanations and implications". Critique: Critical Middle Eastern Studies 16 (3): 209-228.

Jakobson, Linda. 2010. China prepares for an ice-free Arctic. Stockholm: SIPRI Insights on Peace and Security.

Jakobson, Linda and Jingchao Peng. 2012. China's Arctic aspirations. Stochholm: Stockholm International Peace Research Institute.

Ji, You. 2007. “Dealing with the Malacca dilemma: China's effort to protect its energy supply". Strategic Analysis 31 (3): 467-489.

Kim, Woosang and Scott Gates. 2015. "Power transition theory and the rise of China". International Area Studies Review 18 (3): 219-226.

Kindleberger, Charles. 1973. The World in Depression, 1929-1939. Oakland: University of California Press.

Lađevac, Ivona. 2020. „Odgovor Kine na novi bezbednosni izazov“. U: Čovek, prostor, tehnologija, ideje: medunarodna bezbednost u trećoj dekadi 21. veka, uredili Vladimir Ajzenhamer i Nebojša Vuković, 126-151. Beograd: Institut za međunarodnu politiku i privredu i Fakultet bezbednosti Univerziteta u Beogradu.

Lakoff, George. 1991. "Metaphor and war: The metaphor system used to justify war in the Gulf". Peace Research 23 (2): 25-32. 
Langley, William. 2021. “China rejects Mike Pompeo's challenge to its 'nearArctic nation' claim", South China Morning Post, January 6. https://www.scmp.com/news/china/diplomacy/article/3116633/ch ina-rejects-mike-pompeos-challenge-its-near-arctic-nation

Lanteigne, Marc. 2008. “China's Maritime Security and the 'Malacca Dilemma'". Asian Security 4 (2): 143-161.

Lanteigne, Marc. 2016. Ties that Bind: The Emerging Regional Security Complex in the Arctic. Oslo: Norwegian Institute for International Affairs (NUPI).

Layne, Christopher. 2002. “The 'Poster Child for offensive realism': America as a global hegemon". Security Studies 12 (2): 120-164.

Leung, Guy. 2011. “China's energy security: Perception and reality". Energy Policy 39 (3): 1330-1337.

Lim, Soom Kong. 2018. "China's Arctic Policy and the Polar Silk Road Vision". Arctic Yearbook 13 (2): 420-432.

Lukens, Chad. 2013. Cooperation and confrontation in a post-Cold War high north: An international relations approach to Arctic security. Vermillion: University of South Dakota.

Maçães, Bruno. 2018. The Dawn of Eurasia: On the Trail of the New World Order. New Heaven: Yale University Press.

Mackinder, Halford. 1904. The geographical pivot of history. London: Royal Geographical Society.

McNicholas, Michael. 2016. Maritime security: an introduction. Oxford: Butterworth-Heinemann.

[MFA PRC] Ministry of Foreign Affairs of the People's Republic of China. 2018. "Vice Foreign Minister Kong Xuanyou Attends Press Conference on the White Paper Titled China's Arctic Policy". Accessed 5 January 2021. https://www.fmprc.gov.cn/mfa_eng/wjbxw/t1529727.shtml

Monteiro, Nuno. 2014. Theory of unipolar politics. Cambridge: Cambridge University Press.

Øverland, Indra. 2010. “Russia's Arctic energy policy". International Journal 65 (4): 865-878.

Owens, Joshua. 2011. "The Legal Status of the Bering Strait". China Oceans L. Review 13 (3): 84-99.

Page, Jeremy and Gordon Lubold. 2015. “Chinese Navy Ships Came Within 12 Nautical Miles of U.S. Coast", WSJ, September 4. https:/ / www.wsj. 
com/articles/chinese-navy-ships-off-alaska-passed-through-u-sterritorial-waters-1441350488

Proroković, Dušan. 2017. Regionalna bezbednost i teorija realizma: studija slučaja Arktik. Doktorska disertacija. Fakultet bezbednosti, Univerzitet $\mathrm{u}$ Beogradu.

Røseth, Tom. 2014. "Russia's China policy in the Arctic". Strategic Analysis 38 (6): 841-859.

[SC PRC] The State Council the People's Republic of China. 2018. "Full text: China Arctic Policy". Accessed 5 January 2021. english.www.gov.cn/ archive/white_paper/2018/01/26/content_281476026660336.htm

Snidal, Duncan. 1985. "The limits of hegemonic stability theory". International organization 14 (2): 579-614.

Starr, Stephen. 2013. "Attacks in the Suez: Security of the Canal at Risk?". Journal of Commerce 7 (1): 1-7.

Storey, Ian. 2006. "China's 'Malacca Dilemma'”, The Jamestown Foundation, April 12. https://jamestown.org/program/chinas-malacca-dilemma/

Tillman, Henry, Jang Yang and Egill Nielsson. 2018. "The polar silk road: China's new frontier of international cooperation". China Quarterly of International Strategic Studies 4 (3): 345-362.

Wang, Liehui, Yan Zhu, Cesar Ducruet, Mattia Bunel and Yui-Yip Lau. 2018. "From hierarchy to networking: the evolution of the "twenty-firstcentury Maritime Silk Road' container shipping system". Transport Reviews 38 (4): 416-435.

Wegge, Njord. 2011. "The political order in the Arctic: power structures, regimes and influence". The Polar Record 47 (2): 165-178.

Zhan, Li and Pan Ma. 2014. "China's Strategic Vision for the Development of the Northeast Passage". Dongbei Caijing Daxue Xuebao 22 (1): 43-51.

Zhang, Zhong Xiang. 2011. "China's energy security, the Malacca dilemma and responses". Energy policy 39 (12): 7612-7615. 


\section{THE ARCTIC AS THE NORTHERN MARITIME COMPONENT OF THE CHINA'S BELT AND ROAD INITIATIVE}

Abstract: The region of the Arctic is being established as an increasingly intensive field of thematization within the framework of academic discussions in IR. In most cases, the Arctic is designated as a place of growing importance for global peace and stability, as well as an alternative global transit maritime route. The growing economic and political potential of the People's Republic of China has, over the past decade, officially promoted it as a dominant actor in all important occurrences concerning this region. This paper aims to present and analyze the security policy of the People's Republic of China in the Arctic during the past decade as a prerequisite for understanding the current constellation in this area. China defines the geographical area of the Arctic as a North Sea component of its "Belt and Road" initiative, which is why it seeks to preserve regional peace and stability. This study compounds a review of the strategic and doctrinal acts of the People's Republic of China in the field of its foreign policy goals and planned activities for this region. Besides, the significant events that shape the increasingly complex regional security dynamics of the Arctic will be presented. The author applies the postulates of the hegemonic stability theory in which he establishes China as a potential "hegemon" power, and directs the analysis to its "challengers" in the domain of security-political interactions. Additional concretization of the research will be directed towards identification of bilateral relations between China and other countries that lie within the Arctic circle geographically. The findings of this paper will contribute to a more adequate understanding of the peaceful shift of sovereignty over this area and potential disputes that may arise among the key actors.

Keywords: PR China, maritime Belt and Road Initiative, Arctic, regional security, Russia, hegemonic stability theory. 